\title{
Graywater Reuse: The Effects on Income and Agricultural Production Sustainability of Family Farming Systems in the Semiarid Region of Ceará, Brazil
}

\author{
Maria Josiell Nascimento da Silva \\ Dept. of Agricultural Economics, Federal University of Ceara \\ 826, Campus do Pici \\ ZIPCODE 60440-900, Fortaleza, Ceara, Brazil \\ Tel: +55 85 3366-9716 E-mail: nascimentojosiell@hotmail.com \\ Ahmad Saeed Khan \\ Dept. of Agricultural Economics, Federal University of Ceara \\ 826, Campus do Pici \\ ZIPCODE 60440-900, Fortaleza, Ceara, Brazil \\ Tel: +55 85 3366-9716 E-mail: saeed@ufc.br
}

Patrícia Verônica Pinheiro Sales Lima (Corresponding author)

Dept. of Agricultural Economics, Federal University of Ceara

826, Campus do Pici

ZIPCODE 60440-900, Fortaleza, Ceara, Brazil

Tel: +55 85 3366-9716 E-mail: pvpslima@gmail.com

Received: March 12, 2020

doi:10.5296/jas.v9i1.16658
Accepted: June 28, $2020 \quad$ Published: Nov. 19, 2020

URL: https://doi.org/10.5296/jas.v9i1.16658 


\section{Abstract}

The semi-arid region of Ceará is a Brazilian area that is exposed to long and frequent periods of drought. Water scarcity is a threat to the population's well-being and agricultural activities. We evaluated the effects of graywater reuse for agriculture on income and sustainability of agricultural production in the municipality of Iguatu, located in the semiarid region of the state of Ceará. It is an important research because it deals with a strategy that aims to reduce farmers' vulnerability to the lack of water. There are no studies that assess the impacts of water reuse in the region. The propensity score matching technique was applied, and primary data were obtained by interviewing beneficiaries (treated group) and non-beneficiaries (control group). The results showed that the program has effects on sustainable agricultural production of small farmers because of the use of non-aggressive agricultural practices. In the group of beneficiaries, the income is $21.9 \%$ higher than of that in the group of non-beneficiaries. In addition, families that adopt water reuse have $26.8 \%$ higher levels of sustainability than those that do not adopt this strategy of living with drought.

Keywords: reuse of graywater; semiarid; agricultural sustainability

\section{Introduction}

The scarcity of fresh water is a growing global concern, and water shortage tends to worsen due to the ongoing climate change, affecting some segments of society more sharply (Travis et al., 2010). Family farmers are identified as the group most vulnerable to climate change due to its low adaptive capacity and the practice of rainfed agriculture (Cunha et al., 2013; Harvey et al., 2018; Altieri and Koohafkan, 2008). In Brazil, the effects of climate variation are expected to be more intense for family farmers in the semiarid region due to increasing temperatures and more frequent longer droughts in the region (Marengo and Bernasconi, 2015).

In this perspective, rural development strategies in the semiarid region must be aligned with actions to mitigate the effects of climate variations and to create resilience to these stressors. This idea is corroborated by the study by Cunha et al. (2013), who concluded that the use of irrigation reduces the vulnerability of small Brazilian farmers to climate change, qualifying this technique as an adaptive measure. To arrive at such a finding, the authors adopted propensity score matching, allowing them to identify the adoption of irrigation and the returns from irrigated agriculture compared to rainfed agriculture. Projections of temperature and precipitation for the period 2010 to 2099 were used under different climatic scenarios (based on the 4th report of the Intergovernmental Panel on Climate Change), and the results indicate that the average land value of small, irrigating producers is approximately twice the amount of that of rainfed. However, in the semiarid region, the availability of water for irrigation is low, which makes this measure difficult to access for this population (Brasil and Medeiros, 2020; Tsuyuguchi et al. 2020).

Information extracted from scientific articles show that wastewater irrigation to support the livelihoods of farmers already been seen in different countries around the world: United States (Bryck et al., 2008), Japan (Funamiu et al., 2008, Hara et al., 2016). Singapore 
(Lefebvre, 2018), China (Zhang et al., 2018), Australia (Turner et al., 2016), Israel (Rygaard et al., 2011); Cyprus (Kathijotes and Panayiotou, 2013); Spain (Navarro, 2018). According to Perry and Praskievicz (2017) various water reuse projects are located in arid and semi-arid areas. An alternative to increase the possibilities of irrigation in the semiarid region, even if on a small scale, is the reuse of domestic effluents. This source of water, also called graywater, is the water used in the bath and in the sinks, which is collected, treated, and stored and can then be reused for the irrigation of small productions, depending on the volume of water consumed in the home (Morel and Diener, 2006).

The use of graywater for irrigation is a mean to increase the productive capacity of families living in regions with water restriction. The irrigated crop has higher productivity and little variability due to rainfall irregularities, ensuring food security for graywater users (Toze, 2006; Christofidis, 2013). In addition, the disposal of domestic effluents poses a serious risk to environment and health, especially in regions with low sanitation facilities.

In view of the concern for the environment and the search for alternatives to offer or expand the water supply for family farmers in the semiarid region, the Family Biowater Project was initiated in 2014 in the state of Rio Grande do Norte, with the aim to use a graywater system for food production. This project is part of the social technologies offering a simple and low-cost system, promoting the adaptation of farmers to water restriction in an intelligent way, taking advantage of local potentialities (Santos et al., 2016). To promote sustainability in the semiarid region, this project encourages agro-ecological production.

In this way, the program can become a mitigating alternative for three major requirements in the semiarid region of Ceará: i) a source of water for irrigation; ii) reduction of environmental degradation caused by the incorrect disposal of domestic effluents; iii) sustainability in agricultural production.

Based on the experience of Rio Grande do Sul, in 2016, 25 units of the graywater reuse system were implemented in the municipality of Iguatu, with a view to provide a better coexistence of this population with the region's climate. Therefore, this work aims to measure the effect of the Graywater Reuse program on agricultural income and the sustainability of agricultural production by its beneficiaries. The results were obtained from the estimation of the effect of the treatment through the Propensity Score Matching Technique, where the beneficiary group of the graywater reuse (treated) is compared with a group of non-beneficiaries of this technology (control).

In addition to the relevance of dealing with a comprehensive theme that integrated topics such as climate change, measures to adapt to semiarid areas, sustainable rural development, and family farming, the study uses primary data and observations "in loco". In addition, it is the first paper (at the national and international level) which tries to ascertain the impacts of the reuse of graywater on income and sustainability of agricultural production for family farmers. Previous research usually addressed the reuse of water for irrigation in three main approaches: i) risk factors (biological, chemical, sanitary, soil salinization, eutrophication) (Toze, 2006; Moretti et al., 2019; Egbuikwem, Mierzwa and Saroj , 2020), ii) technical aspects (Dolar et al., 2019; Rizzo et al., 2019), and iii) regulations (Helmecke, Fries and 
Schulte, 2020; Mukherjee and Jensen, 2020). Ricart and Rico (2019) draw attention to the role of social scientists in the elaboration of studies capable of offering subsidies to decisions makers in the elaboration of strategies which may provide sustainability of agricultural production and an increase in the income of family farmers. In addition, integrated analyses of the institutional, economic, technological and social factors determine the viability and chances of success of such technology (DOMÈNECH and SAURÍ, 2010).

\section{Description of the Graywater Reuse Program for Agricultural Purposes in the Semiarid Region of Ceará}

Water reuse may have different interpretations, depending on the country. The definition used by the AQUASTAT in Earth Trends is: "the utilization of treated or untreated wastewater for a purpose other than the one that generated it, i.e. it involves a change of use. For instance, the reuse of municipal wastewater for agricultural irrigation." (JIMENEZ AND ASANO, 2008, p. 4).

The implementation of water-collecting systems for reuse is becoming increasingly common in both urban and rural areas and for different uses, such as irrigating gardens and vegetable crops, flushing the toilet, washing vehicles, sidewalks, and windows, extinction of fire, and concrete production, among others (AL-ISMAILI et al., 2017). Some authors list a number of advantages when using wastewater (BENEDUCE et al., 2017). For example, Gohringer (2006) mentions that based on the versatility of uses, the reuse of domestic effluents reduces the demand and preserves the water supply for different uses, such as nutrient recycling, the expansion of irrigated areas, and the reduction in the release of sewage into the environment, thereby encouraging the population to conserve water.

Graywater is a wastewater or domestic effluent from washbasins, sinks, showers, washing machines, and dishwashers. It does not include toilet water, which is called blackwater (AL-MASHAQBEH, GHRAIR AND MEGDAL, 2012). Graywater represents 50 to $80 \%$ of wastewater, and there are several systems for capturing this resource.

Some authors reported opposite data on the effect of gray water on yields from some crops: negative effect on the growth / yield and alteration on the chlorophyll content and total crude protein of beans (IKHAJIAGBE et al. 2020), presence of toxic elements which can affect a person's health (PINTO and MAHESHWARI,2015), odor emission and insect infestation (THAHER et al., 2020).

In the midst of these issues, there are some works in the literature that update the analysis of graywater quality in agriculture, as this is a practice that has been used since the 1980s in European countries such as Italy, France, and Germany (CAIXETA, 2010). The study by Al-Hamaiedeh and Bino (2010) analyzed the quality of vegetable crops irrigated with graywater in Jordan, and the authors concluded that irrigating vegetables with graywater did not show any adverse effects on the chemical properties of fruits or leaves. Mzini and Winter (2015) proposed to test, in an experimental field, the quality of graywater in the planting of vegetables in the city of Mthatha in South Africa, where they observed that graywater was suitable for the irrigation of edible plants and vegetables, finding no evidence that its use may 
pose an environmental risk to the soil in the short term.

The different systems for capturing and filtering to make graywater suitable for use generally contain a graywater storage tank, a filter, and another tank for storing recycled water, also known as "green water" (LIU et al., 2010). This is a generic way of describing the system and, in this work, the focus will be the graywater reuse technology applied for agricultural purposes in the Brazilian semiarid region. The volume of graywater produced depends largely on the availability of water in the residence, as well as on the number of members in the household (RODDA et al., 2011).

The system implemented in this region aims to expand the supply of water for irrigation by improving the coexistence of family farming under semiarid conditions. This technique is inspired by experiences from other countries such as China and Israel, which also suffer from the scarcity of water resources (SANTOS et al., 2016). In addition to the low availability of water for irrigation, there is also a concern about the inadequate disposal of waste and environmental degradation.

Due to the approval of these studies for the use of graywater in the irrigation of food crops and inspired by an international initiative, a project called Family Water or "Bioágua Familiar" (PBF), implemented in 2009 in the state of Rio Grande do Norte, research was conducted in three reuse systems. This project is the result of a partnership between the Dom Helder Câmara Project - PDHC, (Secretariat for Territorial Development - SDT of the Ministry of Agrarian Development - MDA), the International Fund for Agricultural Development - IFAD, Global Environment Facility - GEF Consulting, Assistance and Sustainable Oriented Technical Training - ATOS, and the Federal Rural University of the Semi-Arid - UFERSA (SANTIAGO et al., 2015).

The social technology developed in the PBF consists of a mechanism having of a grease box, a biological filter (which contains two layers of organic material, humus and wood sawdust, and two layers of inorganic material, gravel and pebbles), a tank of reuse to store water from filtration, a drip irrigation system, and an electric pump (SANTIAGO et al., 2015).

This system was developed in two phases. From 2009 to 2013, basic experimental research with the three initial units was performed, and in the second phase, from 2013 to 2015, the units were expanded to 200. From 2015, the project was further expanded and started to benefit other families, and state agencies started to apply this technology in the states of Rio Grande do Norte, Ceará and Bahia (JALFIM and SANTIAGO, 2017).

In 2016, through a partnership between Fundação Banco do Brasil and Instituto Elo Amigo, 25 technology units were implemented in the municipality of Iguatu, in Ceará; they are the oldest units in non-experimental operation in the state of Ceará.

\section{Methodology}

\subsection{Study Area and Sample Description}

The study area is the semiarid region of Ceará due to its historical exposure to drought and the large number of families that benefited from the P1 +2 program (ASA, 2019). The P1 +2 
program $(\mathrm{P} 1=$ One Land and $\mathrm{P} 2=$ Two Waters $)$ aims to consolidate living strategies in the semi-arid climate. In this program, simple and inexpensive technologies are adopted in order to capture water and use it in food production (cisterns, underground dam, tanks, pump of water).

The municipality of Iguatu, located in the central southern region of the state, represents an area susceptible to long periods of drought due to its semiarid tropical climate, characterized by irregular rainfall in time-space. Therefore, this municipality represents characteristics similar to most of the others in the state, with temperatures above $25^{\circ} \mathrm{C}$ (IPECE, 2018). This allows to apply the results found for this municipality to other such areas of Ceará. In addition, this municipality was the first in the state to receive the graywater reuse units for agricultural purposes, which have been in full operation since 2016, and their effects can be evaluated.

The primary data were obtained during the months of July and August of 2018. Information was collected from 25 farming families benefiting from the technology for reusing domestic effluents in Iguatu (farmers had access to the P1+2 Program and Graywater Reuse technology) and from 40 other farming families, which is the control group (that do not have such technology to obtain better matching. Families only used irrigation water provided by the cisterns built by the P1 +2 Program). Both groups, beneficiaries and non-beneficiaries of the Graywater Reuse technology, already had another technology to obtain water for irrigation of small productions, consisting of cisterns that capture rainwater and have a storage capacity of 52,000 liters, built by the P1 +2 Program. Thus, the research was carried out with a total of 65 families, of which 25 had access to the Graywater Reuse technology, which is the treatment group, and the other 40 families only used irrigation water provided by the cisterns, which is the control group.

\subsection{Agricultural Sustainability Index}

To provide a better understanding of the environmental characteristics, considered in this work as the practices adopted in the agricultural production by beneficiaries and non-beneficiaries of the Reuse of Graywater, an Agricultural Production Sustainability Index (ASI) was calculated using Equation 1:

$$
A S I=\frac{1}{w} \sum_{y=1}^{w} I_{y}
$$

ASI = sustainability index of agricultural production

$I=$ score of the $y$-th indicator

$\mathrm{y}=1,2, \ldots, \mathrm{w}$ (indicator)

$\mathrm{w}=$ number of indicators

The production mode of the surveyed farmers is rudimentary with a low level of technology adoption. Produce management is limited to a few agricultural practices that were represented 
in the survey by y indicators: 1) burning practice, 2) use of chemical fertilizer, 3) use of mechanical equipment, 4) use of animal-driven equipment, 5) herbicide use, 6) pesticide use, 7) manure use for soil fertilization, 8) direct plantation practice, 9) soil resting practice, 10) crop rotation practice, 11) use of resistant seeds, 12) manual weeding, 13) use of green manure, 14) use of plant extracts, 15) soil conservation practices. These indicators can be considered as agri-environmental indicators and constitute a tool capable of providing guiding for sustainable agricultural production (YLI-VIIKARI et al., 2007).

The scores were assigned as follows: for indicators, 1 to 6 "yes" answers received a score of 0 because they represent a situation that negatively affects sustainability. The "no" answers received a score of 1 , as they point out a behavior that positively contributes to sustainability. Under the same reasoning, for indicators from 7 to 15, "no" answers received score 0 and "yes" answers received score 1.

The ASI can vary from 0 to 1 . The closer to 1 , the more sustainable are the agricultural practices, that is the production practices are less aggressive. The index can be classified according to that proposed elsewhere (DAMASCENO, KHAN and LIMA, 2011):

I) Low level of sustainability of agricultural production: $0<\mathrm{ASI} \leq 0.5$

II) Medium level of sustainability of agricultural production: $0.5<\mathrm{ASI} \leq 0.8$

III) High level of sustainability of agricultural production: $0.8<\mathrm{ASI} \leq 1$

To evaluate the results, Student's "t" test was used to compare the unpaired means of the treated and control groups (MAIA, KHAN and SOUSA, 2013).

\subsection{Propensity Score Matching}

We measured the effect of the Águas Cinzas Reuse program on the income and environmental sustainability of family farmers in the semiarid region of Ceará. Propensity Score Matching is an econometric procedure capable of providing estimates to achieve this objective, which can be understood as the average effect of treatment on treaties. Therefore, it would be necessary to compare performance in two situations, with and without treatment to be evaluated. However, it is difficult to observe the situation of the same individual before and after receiving treatment.

A major challenge in the impact assessment is the construction of the counterfactual of the treatment group, that is, what would have happened to the beneficiaries had they not participated in the treatment. The best way to construct the factual counter is to randomly select the families that received the technologies to reuse domestic effluents and those that did not. Thus, randomization would be able to provide a necessary balance of the observed and unobserved variables, thereby solving the self-selection problem (GIACHINI, 2016).

Participation in the treatment happened in a non-random way, and the families were differentiated by characteristics that affect both the participation in the treatment and the result of interest, thus characterizing the existence of self-selection, and the simple comparison between the results of the beneficiary and non-beneficiary groups would result in an overestimation of the program (CUNHA et al., 2016). 
Propensity Score Matching is a method that allows the construction of a group against factual data and helps to eliminate possible biases of sample selection in the observed variables (GIACHINI, 2016; SANTOS et al., 2016). This method was developed by Rosenbaum and Rubin (1983) to solve the problem of selection bias that may exist in methods that do not use a common support between the groups to be compared.

The first step of the method is the estimation of the $\mathrm{P}(\mathrm{x})$ propensity score, which is the conditional probability of an individual belonging to the group of beneficiaries given the observable characteristics (ROSENBAUM and RUBIN, 1983). Mathematically, it can be defined as follows:

$$
P(X)=\operatorname{Pr}(C=1 \mid x)
$$

Estimation of the propensity score is obtained through a logit or probit regression, which allows the calculation of the probability of an individual being in the treated group based on observable characteristics $(\mathrm{X})$. These characteristics represent the independent variables of the model, that is, those that can affect the individual's participation in the program. The dependent variable is a dummy that assumes a value of 1 in case the family has graywater reuse technology and 0 in case the family does not have it.

The estimation of the binary model used to estimate the propensity score can be done by Probit or Logit. The selection of the binary model to estimate the probability of participation in the program is made considering several criteria such as the significance of the estimated coefficients, pseudo $\mathrm{R}^{2}$, the Akaike Information criteria (AIC), the Bayesian Information criterion (BIC), the percentage of correctly classified cases, and the area under the ROC (Receiver Operating Characteristic) curve. The latter is a measure of the model's ability to discriminate the categories of the dependent variable (FÁVERO, 2014). Logit and probit models were estimated. The criteria of the best models estimated in each category (Probit and Logit) are presented in Appendix 1A. Neither binary model presents great divergences from the other, and logit was chosen due to its greater ability to differentiate between the two groups: beneficiaries e non beneficiaries (see Appendix 2A for output from model chosen).

The second stage of the model consists of the formation of pairs of beneficiaries and non-beneficiaries who have a propensity score as similar as possible, which makes it possible to analyze the impacts of the programs through matching (MAIA, 2012).

According to Rosenbaum and Rubin (1983), the Average Treatment Effect on the Treated (ATT), that is, the average effect of the program evaluated on the beneficiaries, assuming the existence of a vector of observable characteristics $X$ and being linked conditionally to this, with the units having the same probability of being chosen to compose the groups of beneficiaries or non-beneficiaries, $y^{A s}{ }_{s} y^{c a m}, \mathcal{}, C \mid X$, can be expressed as follows:

$$
A T T=E\left\{E\left[y^{\operatorname{com}} \mid C=1, P(X)\right]-E\left[y^{A s}|c=1, P(X)| c=1\right\}\right.
$$




$$
A T T=E\left\{E\left[y^{\operatorname{com}} \mid C=1, P(X)\right]-E\left[y^{A s}|C=1, P(X)| C=1\right\}\right.
$$

With the propensity score, it is possible to adjust the biases between the groups of beneficiaries and non-beneficiaries; however, for its application, it is necessary to assume two hypotheses:

I) Balancing of observable characteristics: the selection of the sample requires that participation in the programs is independent of the results; and

II) Existence of a common support, that is, $0<\mathrm{P}(\mathrm{X})<1$, so that there is an individual in the group of beneficiaries for each individual in the group of non-beneficiaries.

Different procedures can be used to match the propensity scores of the treated units in relation to the propensity scores of the treated and control group units. According to Gandra and Rodrigues (2018), the most used techniques are Nearest-Neighbor Matching, Radial Matching, and Kernel Matching.

In the pairing by the nearest neighbor, each treatment unit corresponds to the comparison unit with the closest propensity score. It is also possible to choose $\mathrm{n}$ closest neighbors and match (usually, $\mathrm{n}=5$ is used). Correspondence can be made with or without replacement. Replacement correspondence, for example, means that the same non-participant can be used as a correspondence for different participants (handbook). Pairing with replacement has the advantage of avoiding poor pairing, resulting in a reduction in bias, but it has the trade-off of increasing the variance of the estimates due to the reduction in the number of different observations (RODRIGUES, 2016).

In radial pairing, each treated unit is comparable only with the control units whose propensity scores are contained in a neighborhood of the propensity score of treated units defined a priori. If the dimension of the neighborhood (the radius) is very small, there is a chance that some treated units will not be paired due to the lack of control units in the established neighborhood. On the other hand, the smaller the established neighborhood, the better the quality of the neighborhood pairing (BECKER and ICHINO, 2002).

In kernel pairing, all treated units are combined with a weighted average of all units in the control group, with weights that are inversely proportional to the distance between the propensity scores of treaties and controls (BECKER and ICHINO, 2002). In this work, the pairing method to be analyzed will follow the criterion of a better balance between the control and treatment units, that is, the smallest pseudo $\mathrm{R}^{2}$ (CALIENDO and KOPEINING, 2008). The respective test is located in the appendix $3 \mathrm{~A}$.

Maia, Khan and Sousa (2013) affirm that the negative or positive signs of the ATTs indicate the probable impact of the programs on the analyzed variable. After performing the Propensity Score Matching procedure, the Rosenbaum Bounds Sensitivity Test is performed to check for unobservable bias.

\subsection{Sensitivity Analysis}

When there are variables that have not been observed and that are divergent between the control and the treated group, these same variables can affect the outcome variables, that is, 
the results may be skewed. As it is not possible to estimate the size of the bias in the data, Rosenbaum and Rubin (2002) proposed a way of verifying whether the bias affects the results, using Rosenbaum bonds (ROSEMBAUM and RUBIN, 2002; DIPRETE and GANGL, 2004).

Sensitivity analysis can be performed to test the robustness of the results in the presence of bias due to an omitted covariate (CHAGAS, 2009). In this work, the sensitivity analysis aims to verify if there are unobservable biases that mask some effects of the reuse of domestic effluents an income and sustainability of agricultural production of family farmers.

The method recognizes two individuals from their observable characteristics, $i$ and $j$; the probability of individual i's participation in the treatment is as follows:

$$
\tau_{i}=\operatorname{Pr}\left(D_{i}=1 \mid x_{i}\right)=F\left(\beta_{x_{i}}+\gamma u_{i}\right)
$$

Here, $\mathrm{x}_{\mathrm{i}}$ represents the observed characteristics of individual $\mathrm{i}$; $\mathrm{u}_{\mathrm{i}}$ corresponds to the unobserved variable; $\gamma$ is the effect of $u_{i}$ on the decision to participate in the program. When there is no selection bias, $\gamma$ will be equal to zero; therefore, participation in the program takes place exclusively by the observed characteristics. However, if there is selection bias, two individuals with the same observed covariates $\mathrm{x}$ will have different chances of receiving treatment, $\frac{\pi_{i}}{1-\pi_{i}}$ e $\frac{\pi_{j}}{1-\pi_{j}}$.

The odds ratio for participating in the program is given by the following equation:

$$
\frac{\frac{\pi_{i}}{1-\pi_{i}}}{\frac{\pi_{j}}{1-\pi_{j}}}=\frac{\pi_{i}\left(1-\pi_{j}\right)}{\pi_{j}\left(1-\pi_{i}\right)}=\frac{\exp \left(\beta_{x_{j}}+\gamma u_{j}\right)}{\exp \left(\beta_{x_{i}}+\gamma u_{i}\right)} \exp \left[\gamma\left(u_{i}-u_{j}\right)\right.
$$

If individuals have the same observable characteristics, the terms $\beta \mathrm{x}$ are canceled. Thus, if there are no differences in the unobserved variables $\left(u_{i}=u_{j}\right)$ and if these variables do not influence the probability of participation $(\gamma=0)$, the odds ratio will be equal to 1 , implying that there is no selection bias. The limits of the ratio of probabilities of participation in the treatment are expressed as follows:

$$
\frac{1}{e^{y}} \leq \frac{\pi_{i}\left(1-\pi_{j}\right)}{\pi_{j}\left(1-\pi_{i}\right)} \leq e^{y}
$$

Paired individuals have the same probability of participation only if $e^{\gamma}=1$. However, if $e^{\gamma}=2$, then apparently similar individuals in terms of $\mathrm{x}$ will differ in their probabilities of receiving treatment by a factor of up to 2. Thus, according to Rosenbaum and Rubin (2002), $e^{\gamma}$ would be the measure of the degree of rupture from a study free of selection bias. 


\section{Results and Discussion}

To verify the effect of the reuse of domestic effluents used for irrigation of small productions on income and sustainability of agricultural production of beneficiary farmers, the ATT was estimated through Propensity score matching. Thus, the difference obtained between the control and the treated group after pairing will be considered the effect that the program has on agricultural income/ha and the sustainability of agricultural production, which is reflected by the use of agricultural practices.

Table 1 shows the characteristics of the treated and the control groups, where these groups are compared by using statistical tests.

Table 1. Characteristics of beneficiary and non-beneficiary families of the graywater reuse system in Iguatu-CE

\begin{tabular}{|c|c|c|c|c|}
\hline \multicolumn{2}{|l|}{ Characteristics } & \multirow{2}{*}{$\begin{array}{l}\text { Beneficiary } \\
11\end{array}$} & \multirow{2}{*}{$\begin{array}{l}\text { Non-Beneficiary } \\
27\end{array}$} & \multirow{3}{*}{$\begin{array}{l}\text { Tests } \\
\mathrm{Chi}^{2} \\
34.987 * * *\end{array}$} \\
\hline \multirow{2}{*}{ Gender of the chief } & Male & & & \\
\hline & Female & 14 & 13 & \\
\hline Chief age & Median & 46.88 & 55.25 & $\mathrm{t}=23.927 * * *$ \\
\hline \multirow{2}{*}{ Marital status } & Married & 23 & 25 & \multirow{2}{*}{$\begin{array}{l}\text { Fisher } \\
0.009\end{array}$} \\
\hline & Not married & 2 & 15 & \\
\hline Years of study & Average & 6.16 & 3.6 & $\mathrm{t}=29.279 * * *$ \\
\hline \multirow{2}{*}{ Land ownership } & Owner & 19 & 32 & \multirow{2}{*}{$\begin{array}{l}\mathrm{Chi}^{2} \\
0.1457\end{array}$} \\
\hline & Non-owner & 6 & 8 & \\
\hline \multirow{2}{*}{ Condition of household } & Own & 23 & 34 & \multirow{2}{*}{$\begin{array}{l}\mathrm{Chi}^{2} \\
0.6985\end{array}$} \\
\hline & Not own & 2 & 6 & \\
\hline
\end{tabular}

Source: elaborated by the authors from the research data

$* * * \mathrm{p}<0,001$

Regarding the gender of the heads of the families, the beneficiary families were mostly headed by women, while the families in the control group were headed by men, thus having a statistically significant difference at $5 \%$ between the groups. This female dominance in terms of the head of the beneficiary households can be attributed to the focus of ASA actions, promoting female autonomy (MALVEZZI, 2007).

In the northeastern region, the management of agricultural production is dominated by males, who start working at an early age (CALVELLI, LORETO AND SILVA, 2016). In addition, the low education of the rural population is a factor that can make it difficult to accept changes in their production behavior. On the other hand, after being included in the program, women started to deal more directly with the sustainable production of irrigated yards, which may have facilitated the incorporation of the practices passed on in the training offered by Elo Amigo (INSTITUTO ELO AMIGO, 2016).

The average age of beneficiaries was 8 years less than that of non-beneficiaries. This lower average age of the beneficiary group may be one of the reasons why this group had, on average, more years of study. Both differences cited were statistically significant. 
Table 2 presents the indicators (agricultural practices as components of the ASI) and the ASI values of beneficiaries and non-beneficiaries of the graywater reuse system. It should be noted that the group of beneficiaries of the program had a higher ASI. The difference between the compared groups was statistically significant, that is, the agricultural practices adopted by the treated group were less aggressive than those carried out by the control group.

Table 2. Percentages of farmers by adherence to agricultural practices and Agricultural Production Sustainability Index values of beneficiaries and non-beneficiaries of the graywater reuse system in Iguatu-CE

\begin{tabular}{l|l|l|l|l}
\hline Agricultural Practices and ASI & Beneficiary $(\%)$ & $\begin{array}{l}\text { Non-Beneficiary } \\
(\%)\end{array}$ & $\begin{array}{l}\text { Difference } \\
(\%)\end{array}$ & $\boldsymbol{\chi}^{\mathbf{2}}$ \\
\hline Burning practice & 48 & 31.58 & 16.42 & 1.72 \\
\hline Use of chemical fertilizer & 64 & 83.78 & -19.78 & $3.18^{*}$ \\
\hline Use of mechanical equipment & 44 & 44.74 & -0.74 & 0.00 \\
\hline Use of animal-driven equipment & 36 & 13.51 & 22.49 & $4.31^{* *}$ \\
\hline Herbicide use & 48 & 51.35 & -3.35 & 0.07 \\
\hline Pesticide use & 16 & 27.03 & -11.03 & 1.04 \\
\hline Use of manure for soil fertilization & 56 & 64.86 & -8.86 & 0.49 \\
\hline Direct plantation practice & 60 & 48.65 & 11.35 & 0.77 \\
\hline Land-resting & 52 & 29.73 & 22.27 & $3.12^{*}$ \\
\hline Crop rotation practice & 100 & 94.59 & 5.41 & 1.40 \\
\hline Use of resistant seeds & 56 & 48.65 & 7.35 & 0.32 \\
\hline Manual weeding & 28 & 5.41 & 22.59 & $6.14^{* *}$ \\
\hline Use of green manure & 96 & 89.19 & 6.81 & 0.93 \\
\hline Use of plant extracts & 72 & 83.78 & -11.78 & 1.25 \\
\hline Soil conservation practices & 84 & 94.59 & -10.59 & 1.91 \\
\hline ASI & $\mathbf{0 . 6 4}$ & $\mathbf{0 . 5 1}$ & $\mathbf{0 . 1 3}$ & $\mathbf{t}=\mathbf{2 7 . 3 3 * * *}$ \\
\hline
\end{tabular}

Source: elaborated by the authors from the research data

$* * * \mathrm{p}<0,001, * * \mathrm{p}<0,05, * \mathrm{p}<0,10$

ASI - Agricultural Production Sustainability Index

The higher ASI values for the beneficiaries indicate that the program is achieving its objective to promote greater sustainability of agricultural production in the semiarid region (SANTOS et al., 2016).

Table 3 presents the results of the Propensity Score Matching estimation for the variables of interest, which are the agricultural income per hectare and the sustainability of agricultural production. The average difference between the treated and control groups was statistically significant only for ASI, indicating that the program for reusing domestic effluents for irrigation is promoting greater sustainability in the agricultural production of family farmers benefited by the technology. This positive impact of ASI reveals that the program is being effective in fulfilling its objective of promoting a more sustainable agriculture in the Brazilian semiarid region. 
Table 3. Effect of graywater reuse on agricultural income/ha and ASI of family farmers in Iguatu-CE

\begin{tabular}{l|l|l|l|l}
\hline Variables & Beneficiary & Non-Beneficiary & $\begin{array}{l}\text { Difference } \\
(\mathbf{A T T})^{\mathbf{1}}\end{array}$ & T test \\
\hline $\begin{array}{l}\text { Agricultural income / hectare } \\
(\mathrm{R} \$)\end{array}$ & 1760.48 & 1443.86 & 316.62 & 0.23 \\
\hline ASI & 0.6570 & 0.5179 & 0.1390 & $2.48^{* * *}$ \\
\hline
\end{tabular}

Source: prepared by the authors based on the research data

$* * * \mathrm{p}<0,001$

Note 1: The pairing used to calculate the ATT was the closest neighbor with 5 neighbors, chosen by the criterion of the smallest Pseudo R2. Table 1A in the appendix reports the results of pstest for the matching described in the methodology.

Thus, by promoting sustainable agriculture, graywater reuse represents a strategy that combines the needs of people with the limitations of the planet (ROCKSTROM et al., 2017), because in addition to expanding the water supply for irrigation and encouraging more sustainable agricultural practices, by treating domestic effluents, soil and river degradation can be reduced. In addition, irrigation expansion policies and programs, combined with the use of sustainable agricultural practices based on agroecology and better land and water management, are an alternative capable of reducing the adverse effects of intensified agriculture, such as environmental degradation and the increase in water conflicts (GIORDANO, BARRON and UNVER, 2019).

Regarding the agricultural income per hectare, the higher income obtained by beneficiaries was not statistically significant at $5 \%$.

This result can be attributed to the fact that the reuse of domestic effluents is not sufficient to expand agricultural production in large proportion and, consequently, to substantially increase income. This may also be due to the fact that families in the region save water as much as possible in times of drought, directly impacting the volume of water available for reuse in planting. Therefore, graywater reuse alone may not constitute a program that contributes to increases in production and income, but it is efficient in promoting greater environmental sustainability of agricultural production.

To confirm the robustness of the results presented, the sensitivity test was performed using the Rosenbaum limits method (Table 4). 
Table 4. Rosenbaum sensitivity test

\begin{tabular}{l|l|l|l}
\hline Variable of Interest & $\boldsymbol{\Gamma}$ & Sig + & Sig - \\
\hline & 1.00 & 0.000 & 0.000 \\
& 1.05 & 0.000 & 0.000 \\
& 1.10 & 0.000 & 0.000 \\
ASI & 1.15 & 0.000 & 0.000 \\
& 1.20 & 0.000 & 0.000 \\
& 1.25 & 0.000 & 0.000 \\
& 1.30 & 0.000 & 0.000 \\
\hline & 1.00 & 0.000 & 0.000 \\
Agricultural income / hectare & 1.05 & 0.000 & 0.000 \\
& 1.10 & 0.000 & 0.000 \\
& 1.15 & 0.000 & 0.000 \\
& 1.20 & 0.000 & 0.000 \\
& 1.25 & 0.000 & 0.000 \\
& 1.30 & 0.000 & 0.000 \\
\hline
\end{tabular}

Source: prepared by the authors based on the research data

As shown in Table 4, the results described in Table 3 on the impacts of the graywater reuse program are robust, that is, they do not present bias from unobservable variables. The Rosenbaum limit method does not present a formal test of the CIA hypothesis (conditional independence), but it allows to judge the influence of non-observed covariates in the results (ROSENBAUM and RUBIN, 2002).

\section{Final Considerations}

The reuse of domestic effluents for irrigation of small-scale production systems in the semiarid region constitutes a social technology that is still incipient, since the number of units installed is small. The information was collected from farmers using this technology in the semiarid region of Ceará over a longer period, and most of these beneficiaries are women, with an average age of 46 years and with a higher level of education.

Regarding the effect of the program on agricultural income, the results were not significant, indicating that the volume of water available via graywater reuse is not sufficient to confer an increase in production. With regard to agricultural production, the system has a positive effect by promoting a production system compatible with nature, contributing to sustainable agricultural production in the semiarid region of Ceará.

Programs along these lines are capable of reducing the vulnerability of family farmers in the semiarid region, as they offer an alternative for the continuity of production in times of drought and encourages agriculture combined with environmental preservation, which contributes to the maintenance of farmer families in rural areas with greater autonomy over their own resources and in harmony with the environment. 


\section{References}

Al-Hamaiedeh, H., \& Bino, M. (2010). Effect of treated grey water reuse in irrigation on soil and plants. Desalination, 256(1-3), 115-119. https://doi.org/10.1016/j.desal.2010.02.004

Al-Ismaili, A. M., Ahmed, M., Al-Busaidi, A., Al-Adawi, S., Tandlich, R., \& Al-Amri, M. (2017). Extended use of grey water for irrigating home gardens in an arid environment. Environmental Science and Pollution Research, 24(15), 13650-13658. https://doi.org/10.1007/s11356-017-8963-z

Al-Mashaqbeh, O. A., Ghrair, A. M., \& Megdal, S. B. (2012). Grey water reuse for agricultural purposes in the Jordan Valley: Household survey results in Deir Alla. Water, 4(3), 580-596. https://doi.org/10.3390/w4030580

Altieri, M. A., \& Koohafkan, P. (2008). Enduring farms: climate change, smallholders and traditional farming communities (Vol. 6). Penang: Third World Network (TWN).

ASA - ARTICULAÇÃO DO SEMIÁRIDO BRASILEIRO. disponível em: <http://www.asabrasil.org.br>. Acesso em: 28/08/2019

Becker, S. O., \& Ichino, A. (2002). Estimation of average treatment effects based on propensity scores. The stata journal, 2(4), 358-377. https://doi.org/10.1177/1536867X0200200403

Beneduce, L., Gatta, G., Bevilacqua, A., Libutti, A., Tarantino, E., Bellucci, M., Troiano, E., Spano, G. (2017). Impact of the reusing of food manufacturing wastewater for irrigation in a closed system on the microbiological quality of the food crops. Int. J. Food Micribiol. 260, 51-58. https://doi.org/10.1016/j.ijfoodmicro.2017.08.009

Brasil, P., \& Medeiros, P. (2020). NeStRes-model for operation of Non-Strategic Reservoirs for irrigation in drylands: model description and application to a semiarid basin. Water Resources Management, 34(1), 195-210. https://doi.org/10.1007/s11269-019-02438-x

Bryck, J., Prasad, R., Lindley, T., Davis, S., Carpenter, G., (2008). National Database of Water Reuse Facilities Summary Report. Water Reuse Foundation, Alexandria, Virginia (Accessed 24 may). https://www.waterboards.ca.gov/water_issues/programs/grants_loans/water_recycling/researc h/02_004_01.pdf

Caixeta, C. E. T. (2010). Avaliação do atual potencial de reuso de águas cinzas no estado do Ceará e propostas para um sistema de gestão. (Doctoral dissertation, Universidade de São Paulo).

Caliendo, M., \& Kopeinig, S. (2008). Some practical guidance for the implementation of propensity score matching. Journal of economic surveys, 22(1), 31-72. https://doi.org/10.1111/j.1467-6419.2007.00527.x

Calvelli, H. G., de Loreto, M. D. D. S., \& Silva, E. C. (2016). As relações de gênero e a Agricultura Familiar de Pesqueira (PE): o empoderamento feminino a partir da produção de matérias-primas para o biodiesel. Anais, 1-21. 
Chagas, A. L. S. (2009). Três ensaios sobre o setor produtor de cana-de-açúcar no Brasil (Doctoral dissertation, Universidade de São Paulo).

Christofidis, D. (2013). Água, irrigação e agropecuária sustentável. Revista de Política Agrícola, 1, 115-127.

Cunha, D. A. D., Coelho, A. B., Féres, J. G., Braga, M. J., \& Souza, E. C. D. (2013). Irrigação como estratégia de adaptação de pequenos agricultores às mudanças climáticas: aspectos econômicos. Revista de Economia e Sociologia Rural, 51(2), 369-386. https://doi.org/10.1590/S0103-20032013000200009

Damasceno, N. P., Khan, A. S., \& Lima, P. V. P. S. (2011). O impacto do Pronaf sobre a sustentabilidade da agricultura familiar, geração de emprego e renda no Estado do Ceará. Revista de Economia e Sociologia Rural, 49(1), 129-156. https://doi.org/10.1590/S0103-20032011000100006

DiPrete, T. A., \& Gangl, M. (2004). 7. Assessing bias in the estimation of causal effects: Rosenbaum bounds on matching estimators and instrumental variables estimation with imperfect instruments. Sociological methodology, 34(1), 271-3. https://doi.org/10.1111/j.0081-1750.2004.00154.x

Dolar, D., Racar, M., Karadakić, K., Čavarović, N., Glumac, N., \& Košutić, K. (2019, January). Reuse of municipal wastewater for agricultural irrigation by membrane processes. In 8th International Conference Water for all. https://doi.org/10.15255/CABEQ.2018.1571

Domènech, L., \& Saurí, D. (2010). Socio-technical transitions in water scarcity contexts: Public acceptance of greywater reuse technologies in the Metropolitan Area of Barcelona. Resources, Conservation and Recycling, 55(1), 53-62. https://doi.org/10.1016/j.resconrec.2010.07.001

Egbuikwem, P. N., Mierzwa, J. C., \& Saroj, D. P. (2020). Assessment of suspended growth biological process for treatment and reuse of mixed wastewater for irrigation of edible crops under hydroponic conditions. Agricultural Water Management, 231, 106034. https://doi.org/10.1016/j.agwat.2020.106034

Fávero, P. (2014). Métodos quantitativos com stata: procedimentos, rotinas e análise de resultados. 1 ed. Rio de Janeiro: Elsevier.

Funamiu, N., Onitsuka, T., Hatori, S., (2008). Water reuse in Japan. In: Jimenez, B., Asano, T. (Eds.), Water Reuse: An International Survey of Current Practice, Issues and Needs. IWA, London, pp. 373-386.

Gandra, J. M. D. F. V., \& Rodrigues, C. T. (2019). O impacto da educação em tempo integral no desempenho escolar: uma avaliação do programa mais educação. Anais, 1-21.

Gichini, G. F. Análise econômica do impacto do manejo integrado de pragas na produtividade da cana-de-açúcar do Estado de São Paulo. Piracicaba-SP: Dissertação (Mestrado)-USP/ Escola Superior de Agricultura "Luiz de Queiroz". 2016 
Giordano, M., Barron, J., \& Ünver, O. (2019). Water Scarcity and Challenges for Smallholder Agriculture. In Sustainable Food and Agriculture (pp. 75-94). Academic Press. https://doi.org/10.1016/B978-0-12-812134-4.00005-4

Göhringer, S. S. (2006). Uso Urbano Não Potável de Efluentes de Estação de Tratamento de Esgoto Sanitário: Estudo de Caso Município de Campo Largo. Curitiba, PUCPR. (Master Dissertation).

Hara, K., Kuroda, M., Yabar, H., Kimura, M., Uwasu, M., 2016. Historical development of wastewater and sewage sludge treatment technologies in Japan - an analysis of patent data from the past 50 years. Environ. Dev. 19, 59-69. https://doi.org/10.1016/j.envdev.2016.05.001

Harvey, C. A., Saborio-Rodríguez, M., Martinez-Rodríguez, M. R., Viguera, B., Chain-Guadarrama, A., Vignola, R., \& Alpizar, F. (2018). Climate change impacts and adaptation among smallholder farmers in Central America. Agriculture \& Food Security, 7(1), 57. https://doi.org/10.1186/s40066-018-0209-х

Helmecke, M., Fries, E., \& Schulte, C. (2020). Regulating water reuse for agricultural irrigation: risks related to organic micro-contaminants. Environmental Sciences Europe, 32(1), 4. https://doi.org/10.1186/s12302-019-0283-0

Ikhajiagbe, B., Ohanmu, E. O., Ekhator, P. O., \& Victor, P. A. (2020). The effect of laundry grey water irrigation on the growth response of selected local bean species in Nigeria. Agricultural Science \& Technology (1313-8820), 12(1). https://doi.org/10.15547/ast.2020.01.012

INSTITUTO ELO AMIGO. Reuso de águas cinzas chega no Iguatu pela parceria entre Elo Amigo e Fundação Banco do 2016. <http://www.eloamigo.org.br/?view=article\&id=44852:reuso-de-aguas-cinzas-chega-no-iguat u-pela-parceria-entre-elo-amigo-e-fundacao-banco-do-brasil> Access 08/29/2019

IPECE - INSTITURO DE PESQUISA E ESTRATÉGIA ECONÔMICA DO CEARÁ. Perfil básico municipal. Fortaleza, 2017. Disponível em < https://www.ipece.ce.gov.br/perfil-municipal-2017/> Access 08/29/2019.

Jalfim, F., Santiago, F. S. O sistema bioágua familiar. 2017. Disponível em: < https://www.cta.int/en/article/o-sistema-bio\%C3\%A1gua-familiar-sid0509a8dda-3b11-4382-a f93-680d4c6d7bc0> Access 08/29/2019.

Jimenez, B., \& Asano, T. (2008). Water reclamation and reuse around the world. In: Water Reuse: an international survey of current practice, issues and needs. London: IWA.

Kathijotes, N., \& Panayiotou, C. (2013). Wastewater reuse for irrigation and seawater intrusion: evaluation of salinity effects on soils in Cyprus. J. Water Reuse Desal., 3(4), 392-401. https://doi.org/10.2166/wrd.2013.072

Lefebvre, O. (2018). Beyond NEWater: an insight into Singapore's water reuse prospects. Curr. Opin. Environ. Sci. Health 2, 26-31. https://doi.org/10.1016/j.coesh.2017.12.001 
Liu, S., Butler, D., Memon, F. A., Makropoulos, C., Avery, L., \& Jefferson, B. (2010). Impacts of residence time during storage on potential of water saving for grey water recycling system. Water research, 44(1), 267-277. https://doi.org/10.1016/j.watres.2009.09.023

Maia, G. S. (2012). Avaliação e sustentabilidade dos programas de assentamento agrícola no estado do Ceará um estudo de caso. Universidade Federal do Ceará (UFC). Departamento de Economia Agrícola, Fortaleza. (Master Dissertation).

Maia, G. S., Khan, A. S., \& Sousa, E. P. D. (2013). Avaliação do impacto do Programa de Reforma Agrária Federal no Ceará: um estudo de caso. Economia Aplicada, 17(3), 379-398. https://doi.org/10.1590/S1413-80502013000300007

Malvezzi, R. (2007). Semi-Árido: uma visão holística. Coleção Pensar o Brasil.

Marengo, J. A., \& Bernasconi, M. (2015). Regional differences in aridity/drought conditions over Northeast Brazil: present state and future projections. Climatic Change, 129(1-2), 103-115. https://doi.org/10.1007/s10584-014-1310-1

Morel, A. (2006). Greywater management in low and middle-income countries (No. 628.2 G842g). Dubenforf, CH: Swiss Federal Institute of Aquatic Science and Technology.

Moretti, M., Van Passel, S., Camposeo, S., Pedrero, F., Dogot, T., Lebailly, P., \& Vivaldi, G. A. (2019). Modelling environmental impacts of treated municipal wastewater reuse for tree crops irrigation in the Mediterranean coastal region. Science of the Total Environment, 660, 1513-1521. https://doi.org/10.1016/j.scitotenv.2019.01.043

Mukherjee, M., \& Jensen, O. (2020). Making water reuse safe: A comparative analysis of the development of regulation and technology uptake in the US and Australia. Safety Science, 121, 5-14. https://doi.org/10.1016/j.ssci.2019.08.039

Mzini, L. L., \& Winter, K. (2015). Analysis of grey-water used for irrigating vegetables and possible effects on soils in the vicinity of Umtata Dam, Eastern Cape. Water Sa, 41(1), 115-120. https://doi.org/10.4314/wsa.v41i1.14

Navarro, T. (2018). Water reuse and desalination in Spain - challenges and opportunities. J. Water Reuse Desal. https://doi.org/10.2166/wrd.2018.043. In press. https://doi.org/10.2166/wrd.2018.043

Perry, D. M., \& Praskievicz, S. J. (2017). A new era of big infrastructure? (Re)developing water storage in the U.S. West in the context of climate change and environmental regulation. Water Altern., 10(2), 437-454.

Pinto, U., \& Maheshwari, B. L. (2015). Sustainable graywater reuse for residential landscape irrigation-a critical review, Chinese Journal of Population Resources and Environment, 13(3), 250-264. https://doi.org/10.1080/10042857.2015.1059790

Ricart, S., \& Rico, A. M. (2019). Assessing technical and social driving factors of water reuse in agriculture: A review on risks, regulation and the yuck factor. Agricultural water management, 217, 426-439. https://doi.org/10.1016/j.agwat.2019.03.017 
Rizzo, L., Gernjak, W., Krzeminski, P., Malato, S., McArdell, C. S., Perez, J. A. S., ... Fatta-Kassinos, D. (2019). Best available technologies and treatment trains to address current challenges in urban wastewater reuse for irrigation of crops in EU countries. Science of The Total Environment, 136312. https://doi.org/10.1016/j.scitotenv.2019.136312

Rockström, J., Williams, J., Daily, G., Noble, A., Matthews, N., Gordon, L., ... de Fraiture, C. (2017). Sustainable intensification of agriculture for human prosperity and global sustainability. Ambio, 46(1), 4-17. https://doi.org/10.1007/s13280-016-0793-6

Rodda, N., Salukazana, L., Jackson, S. A. F., \& Smith, M. T. (2011). Use of domestic greywater for small-scale irrigation of food crops: Effects on plants and soil. Physics and Chemistry of the Earth, Parts A/B/C, 36(14-15), 1051-1062. https://doi.org/10.1016/j.pce.2011.08.002

Rodrigues, A. S. (2016). Avaliação do impacto do Projeto Hora de Plantar sobre a sustentabilidade dos agricultores familiares da Microrregião do Cariri (CE): o caso o híbrido. (Doctoral dissertation, Universidade Federal do Ceará).

Rosenbaum, P. R., \& Rubin, D. B. (1983). The central role of the propensity score in observational studies for causal effects. Biometrika, 70(1), 41-55. https://doi.org/10.1093/biomet/70.1.41

Rosenbaum, P. R., Rubin, D. (2002). Observational Studies. New York: Springer. https://doi.org/10.1007/978-1-4757-3692-2

Rygaard, M., Binning, P. J., Hans-Jorgen, A. (2011). Increasing urban water self-sufficiency: new era, new challenges. J. Environ. Manage. 92(1), 185-194. https://doi.org/10.1016/j.jenvman.2010.09.009

Santiago, F., Jalfim, F., Blackburn, R., Dombroski, S., Monteiro, L., Nanes, M., ... Santos, W. (2015). Manual de implantação e manejo do sistema bioágua familiar: reúso de água cinza doméstica para a produção de alimentos na agricultura familiar do semiárido brasileiro. Caraúbas: Atos.

Santos, C. F., Guedes Maia, Z. M., Stradiotto Siqueira, E., \& Rozendo, C. (2016). A contribuição da Bioágua para a segurança alimentar e sustentabilidade no Semiárido Potiguar brasileiro. Sustainability in Debate/Sustentabilidade em Debate, 7(3). https://doi.org/10.18472/SustDeb.v7n0.2016.18347

Santos, P. F. A., Almeida, A. N., Lacerda, L. P. T., Silva, S. M., Brito, R. A. (2016). Os impactos do programa município verde (PMV) no controle do desmatamento da Amazônia: uma análise usando propensity score matching. Uberlândia-MG: Economia-Ensaios, 30(2), 35-64. https://doi.org/10.14393/REE-v30n2a2016-2

Thaher, R. A., Mahmoud, N., Al-Khatib, I. A., \& Hung, Y. T. (2020). Reasons of Acceptance and Barriers of House Onsite Greywater Treatment and Reuse in Palestinian Rural Areas. Water, 12(6), 1679. https://doi.org/10.3390/w12061679

Toze, S. (2006). Reuse of effluent water-benefits and risks. Agricultural water management, 
80(1-3), 147-159. https://doi.org/10.1016/j.agwat.2005.07.010

Travis, M. J., Wiel-Shafran, A., Weisbrod, N., Adar, E., \& Gross, A. (2010). Greywater reuse for irrigation: effect on soil properties. Science of the Total Environment, 408(12), 2501-2508. https://doi.org/10.1016/j.scitotenv.2010.03.005

Tsuyuguchi, B. B., Morgan, E. A., Rêgo, J. C., \& de Oliveira Galvão, C. (2020). Governance of alluvial aquifers and community participation: a social-ecological systems analysis of the Brazilian semi-arid region. Hydrogeology Journal. https://doi.org/10.1007/s10040-020-02160-8

Turner, A., Mukheibir, P., Mitchell, C., Chong, J., Retamal, M., Murta, J., Carrard, N., Delaney, C. (2016). Recycled water-lessons from Australia on dealing with risk and uncertainty. Water Pract. Technol., 11(1), 127-138. https://doi.org/10.2166/wpt.2016.015

Yli-Viikari, A., Hietala-Koivu, R., Huusela-Veistola, E., Hyvönen, T., Perälä, P., \& Turtola, E. (2007). Evaluating agri-environmental indicators (AEIs)-use and limitations of international indicators at national level. Ecological Indicators, 7(1), 150-163. https://doi.org/10.1016/j.ecolind.2005.11.005

Zhang, S., Yao, H., Lu, Y., Shan, D., Yu, X. (2018). Reclaimed water irrigation effect on agricultural soil and maize (Zea mays L.) in Northern China. Clean-Soil Air Water, 46. https://doi.org/10.1002/clen.201800037

\section{Appendix}

Appendix A.

Table 1A. Criteria for choosing the binary model to estimate $\mathrm{P}(\mathrm{x})$

\begin{tabular}{c|c|c}
\hline \multirow{2}{*}{ Criteria } & \multicolumn{2}{|c}{ Model } \\
\cline { 2 - 3 } & Probit & Logit \\
\hline AIC & 73,0827 & 72.9465 \\
BIC & 94,3540 & 94.2179 \\
ROC & 0,8789 & 0.8854 \\
Pseudo R $^{2}$ & 0,3651 & 0.3668 \\
Correctly classified cases & $79,03 \%$ & $77.42 \%$ \\
\hline
\end{tabular}

Source: prepared by the authors based on the research data 
Table 2A. Logistic model used to estimate $\mathrm{P}(\mathrm{x})$

\begin{tabular}{l|l|l}
\hline \multicolumn{1}{c|}{ Variables } & \multicolumn{1}{c}{ coefficient } & \multicolumn{1}{c}{ p-value } \\
\hline Sex & -1.2382 & $0.007^{*}$ \\
\hline Years of study & 0.1901 & $0.004^{*}$ \\
\hline Marital status & -0.1996 & 0.597 \\
\hline No. of male farmers & 0.7363 & $0.022^{* *}$ \\
\hline Time residing on site & 0.0244 & 0.100 \\
\hline Receives rural credit & -0.4369 & 0.370 \\
\hline Burns & -1.1047 & $0.043^{* *}$ \\
\hline No-till & -0.4403 & 0.416 \\
\hline Weeding manually & 1.3073 & $0.038^{* *}$ \\
\hline
\end{tabular}

Source: prepared by the authors based on the research data

Table 3A. PStest for matchings by nearest neighbor, Kernel and Radius

\begin{tabular}{c|c}
\hline Matching method & PSEUDO R $^{\mathbf{2}}$ \\
\hline Nearest Neighbor (5) & 0.090 \\
Radius (0.1) & 0.116 \\
Kernel (0.1) & 0.120 \\
\hline
\end{tabular}

Source: prepared by the authors based on the research data

\section{Copyright Disclaimer}

Copyright for this article is retained by the author(s), with first publication rights granted to the journal.

This is an open-access article distributed under the terms and conditions of the Creative Commons Attribution license (http://creativecommons.org/licenses/by/4.0/). 